\title{
PENDAPAT KEPALA SEKOLAH DAN GURU PAMONG TENTANG KOMPETENSI PEDAGOGIK MAHASISWA PLP PGPAUD FIP UPI TAHUN AKADEMIK 2014-2015
}

\author{
Syifa Rohmati Mashfufah, Ocih Setiasih, Cucu Eliyawati \\ Universitas Pendidikan Indonesia, Jln. Setiabudhi no. 229 Bandung
}

\begin{abstract}
Principals and Mentor-Teachers' Opinionson The Pedagogic Competence Of PGPAUD FIP UPI Students Taking Professional Internship Program Academic Year 2014-2015. The research aims to find the opinions of principals and mentor-teachers on the pedagogic competence of PGPAUD FIP UPI Students taking professional internship program in the academic year of 2014-2015. It adopted descriptive survey method. The population and sample of this research were all principals and mentor-teachers who supervised the professional internship program for 2014-2015 academic year. Data were collected using close-ended questionnaires as the instrument and were then analyzed with descriptive statistic. The principals' opinion on the pedagogic competence of PGPAUDstudents taking professional internship program was good with a score of $72.93 \%$. Mentor-teachers' opinion on the pedagogic competence of PGPAUD students taking professional internship program was good as well with a score of $62.06 \%$. The research recommends that the instructional strategies used in improving pedagogic competence be more applicative, especially for the strategies used in teaching instructional evaluation, so that in addition to being able to identify concepts of instructional evaluation, students can practice applying the techniques in the field. Future research is suggested to raise issues on pedagogic competence in the study program of Early Childhood Teacher Education in Indonesia to reveal further results and findings. The study program of Early Childhood Education is recommended to create more competent graduates of early childhood education teachers.
\end{abstract}

Keywords : pedagogic competence, PGPAUD students taking professional internship program

\begin{abstract}
Abstrak : Pendapat Kepala Sekolah dan Guru Pamong tentang Kompetensi Pedagogik Mahasiswa PLP PGPAUD FIP UPI Tahun Akademik 2014-2015. Tujuan penelitian ini adalah untuk mengetahui pendapat kepala sekolah dan guru pamong tentang kompetensi pedagogik mahasiswa PLP PGPAUD FIP UPI tahun akademik 2014-2015. Metode yang digunakan survei deskriptive. Populasi dan sampel pada penelitian ini adalah seluruh kepala sekolah dan guru pamong yang menjadi pembimbing program PLP tahun akademik 2014-2015. Alat pengumpulan data penelitian ini menggunakan angket tertutup yang kemudian dianalisis dengan statistika deskriptif. Kepala sekolah berpendapat tentang kompetensi pedagogik mahasiswa PLP PGPAUD adalah baik dengan nilai $72,93 \%$. Pendapat guru pamang tentang kompetensi pedagogik mahasiswa PLP PGPAUD adalah baik dengan nilai 62,06\%. Rekomendasi penelitian ini agar strategi pembelajaran yang digunakan dalam meningkatkan kompentensi pedagogik lebih aplikatif, khususnya untuk strategi pembelajaran matakuliah evaluasi pembelajaran, sehingga mahasiswa selain dibekali pengetahuan mengenai konsep-konsep evaluasi pembelajaran, mahasiswa juga dapat berlatih untuk menggunakan teknik-teknik penilaian di lapangan secara langsung. Untuk penelitian selanjutnya agar dapat mengangkat permasalahan mengenai kompetensi pedagogik pada program studi PGPAUD di Indonesia sehingga diharapkan peneliti mendapatkan
\end{abstract}


temuan baru dan memberikan rekomendasi untuk program studi PGPAUD dan menghasilkan lulusan-lulusan guru PAUD yang lebih baik lagi.

Kata Kunci : kompetensi pedagogik, mahasiswa PLP PGPAUD

Menurut Isjoni (2006) Pendidikan guru merupakan salah satu yang terpenting untuk memajukan suatu bangsa, ditangan gurulah terletak arah dan tujuan masa depan anak bangsa. Menjadi seorang guru bukanlah hal yang mudah, dibutuhkan komitmen atau kesediaan dan kemampuan untuk memenuhi tugas serta perannya dengan penuh tanggung jawab sebagai pendidik. Kualitas guru akan berdampak pada mutu pembelajaran, dimana pihak gurulah yang akan banyak bersentuhan langsung dengan siswanya dalam proses pembeajaran dan akan berimplikasi pada kualitas output pendidikan.

Pendidikan guru harus membekali para lulusannya untuk memiliki kompetensi guru. Sesuai dengan Undang-Undang Nomor 14 Tahun 2005 tentang Guru dan Dosen kompetensi merupakan seperangkat pengetahuan, keterampilan, dan perilaku yang dihayati, dikuasai, dan diwujudkan dalam melaksanakan tugas keprofesionalannya. Pembekalan ini tentunya bukan hanya tataran teoritis saja tetapi juga harus menjangkau pada aplikasi riil di lapangan (Panduan PPL, 2014). Dalam Peraturan Pemerintah Nomor 19 Tahun 2005 tentang Standar Pendidikan dan Tenaga Kependidikan bahwa kompetensi sebagai agen pembelajar pada jenjang pendidikan dasar dan menengah serta pendidikan anak usia dini (Nuraini, 2012).

Pada Undang-Undang Republik Indonesia Nomor 14 Tahun 2005 bagian kesatu pasal 10 tentang Guru dan Dosen dijelaskan bahwa "Kompetensi guru sebagaimana yang dimaksud dalam pasal 8 meliputi kompetensi pedagogik, kompetensi kepribadian, kompetensi sosial, dan kompetensi profesional melalui pendidikan profesi. "Kompetensi pedagogik adalah kemampuan guru dalam mengelola pembelajaran peserta didik yang meliputi pemahaman terhadap peserta didik, perancangan dan pelaksanaan pembelajaran, evaluasi hasil belajar dan pengembangan peserta didik untuk mengaktualisasikan berbagai potensi yang dimilikinya (Rachmawati \& Daryanto, 2013, hlm 76). Hal ini berimplikasi terhadap guru untuk dapat menguasai teori belajar dan prinsipprinsip belajar serta mampu untuk mengembangkan kurikulum satuan pendidikan (Fadillah, 2013). Kompetensi kepribadian adalah karakterstik pribadi yang harus dimiliku guru sebagai individu yang mantap, stabil, dewasa, arif, dan wibawa, menjadi tauladan bagi peserta didik, dan berakhlak mulia (Fadillah, 2013, hlm. 88). Kompetesi sosial adalah kemampuan guru untuk berkomunikasi dan bergaul secara efektif, berinteraksi dengan peserta didik, sesama pendidik, tenaga kependidikan, orang tua atau wali peserta didik, dan masyarakat sekitar (Fadillah, 2012).

Menurut Syaripudin (2009) pedagogik (ilmu pendidikan anak) pada dasarnya merupakan sistem teori pendidikan anak yang merupakan suatu keharusan (diperlukan) dalam rangka praktek mendidik anak. Sistem teori pendidikan anak memiliki 
hubungan yang komplementer dengan praktek pendidikan anak, dimana pedagogik merupakan suatu sistem pengetahuan tentang pendidikan anak yang diperlukan sebagai dasar atau landasan bagi praktek pendidikan anak dan sebagai standar (kriteria) keberhasilan praktek pendidikan anak (Syaripudin, 2009). Begitupun sebaliknya teori pendidikan anak sebenarnya bersumber atau dibangun dari praktek pendidikan anak, bahkan praktek pendidikan anak dapat menjadi sarana untuk penguji kebenaran dari teori pendidikan anak (Syaripudin, 2009). Dalam praktek mendidik anak tentu harus dipertanggungjawabkan secara ilmiah, sehingga tidak terjadi kesalahan, baik itu kesalahan secara konseptual, teknis, dan yang bersumber pada struktur kepribadian pendidik (Syaripudin, 2009).

Salah satu yang menjadi perhatian khusus adalah kompetensi guru Taman Kanak-kanak (TK) adalah kompetensi pedagogik. Sejalan dengan data yang diperoleh bahwa dari hasil jejak pendapat yang dilakukan Farwan, dkk (t.t) bahwa terdapat beberapa kepala TK dan pengurus lembaga TK di Kota Pontianak dimana guru masih memiliki kompetensi pedagogik yang kurang diantaranya guru masih menggunakan pembelajaran yang kaku dan monoton seperti mengajar untuk sekolah menengah diantaranya anak belajar membaca, menulis dan berhitung tanpa adanya pendekatan pembelajaran PAUD seperti bermain sambil belajar, kemudian cara berkomunikasi dengan anak kurang baik dimana terkadang guru berteriak sambil berkata kasar dan jarang melakukan kegiatan evaluasi . Selain itu hasil penelitian yang dilakukan oleh Mariana (2008) juga dalam penelitiannya Developing The Counseling-Based Learning Program For Kindergarten ditemukan bahwa guru yang sudah memiliki kualifiensikasi S1 dalam proses pelaksanaan pembelajaran di TK memiliki kemampuan yang kurang dalam kompetensi pedagogik dimana masih terlihat perlakuan-perlakuan yang tidak sesuai dengan pendekatan pembelajaran untuk anak TK, seharusnya guru dapat memperhatikan atau memahami karakteristik anak dan perkembangan dalam belajar, sehingga anak merasa nyaman berada di lingkungan yang kondusif untuk belajar dan bermain. Dari informasi tersebut terlihat bahwa masih terdapat lulusan guru PAUD yang belum dapat memenuhi kompetensi dimana guru belum dapat melaksanakan proses pembelajaran sesuai dengan pemahaman terhadap anak usia dini. Seharusnya guru PAUD bahkan calon guru PAUD dapat dipersiapkan untuk dapat memenuhi kompetensi pedagogik yang baik dimana guru memiliki pengetahuan praktek mendidik anak dan dapat melakukan praktek mendidik anak dengan mengacu pada ilmu mendidik anak yang relevan sehingga guru PAUD terhindar dari kesalahan-kesalahan dalam praktek mendidik anak (Syaripudin, 2009).

Program Studi S1 Pendidikan Guru Pendidikan Anak Usia Dini (PGPAUD) Fakultas Ilmu Pendidikan (FIP) Universitas Pendidikan Indonesia (UPI) merupakan lembaga pendidikan yang akan menghasilkan lulusannya menjadi guru pada satuan pendidikan Taman Kanak-kanak (TK), Raudhatul Athfal (RA), Kelompok Bermain (KB), Tempat Penitipan Anak (TPA), Satuan Pendidikan Anak Usia Dini Sejenis (SPS), atau bentuk lain yang sederajat, maka dipandang perlu untuk melaksanakan program praktek latihan secara riil di satuan-satuan PAUD (Panduan PPL, 2014). Program tersebut dikemas dalam mata kuliah Program Latihan Profesi (PLP). PLP merupakan matakuliah wajib dengan bobot 4 (empat) SKS yang harus 
ditempuh mahasiswa yang diposisikan sebagai muara mata kuliah yang ditempuh oleh mahasiswa S1 PGPAUD UPI dan sebagai pengembangan dan kulminasi dari proses kurikuler S1 PGPAUD yang telah di tempuh oleh para mahasiswanya, selain itu mahasiswa dituntut untuk melakukan latihan terbimbing dalam memenuhi kompetensi pedagogik, profesional, kepribadian, dan sosial yang dibimbing oleh dosen, kepala sekolah, dan guru pamong (Panduan PPL, 2014). Kompetensi tersebut harus menjadi acuan mahasiswa maupun semua pihak yang terlibat dalam pelaksanaan kegiatan PLP Program S1 PGPAUD FIP UPI, sehingga dengan adanya kegiatan PLP ini dapat menghantarkan mahasiswa S1 PGPAUD untuk menjadi lulusan calon guru yang profesional dan diharapkan dapat menguasai kemampuan keguruan yang utuh serta terpadu, sehingga siap untuk memenuhi tugas pendidikan (Panduan PPL, 2014). Sebagaimana yang diamanahkan di dalam Undang-Undang Republik Indonesia Nomor 14 Tahun 2005 tentang Guru dan Dosen bahwa "Guru adalah pendidik profesional dengan tugas utama mendidik, mengajar, membimbing, mengarahkan, melatih, menilai, dan mengevaluasi peserta didik pada pendidikan anak usia dini jalur formal, pendidikan dasar, dan pendidikan menengah". Peraturan Pemerintah Nomor 74 Tahun 2008 tentang Guru menyatakan bahwa "Kewajiban guru mencakup kegiatan pokok yaitu merencanakan pembelajaran, melaksanakan pembelajaran, menilai hasil pembelajaran, membimbing dan melatih peserta didik, serta melaksanakan tugas tambahan yang melekat pada pelaksanaan pembelajaran".

Namun bila dilihat dari kondisinya ternyata mahasiswa atau calon guru PAUD pada program studi S1 PGPAUD PGPAUD FIP memiliki permasalahan dalam kompetensi pedagogik. Hal tersebut berdasarkan dari hasil wawancara yang peneliti lakukan sebelum melakukan penelitian, dan dapat disampaikan bahwa dari hasil jajak pendapat dengan guru pamong bahwa selama mahasiswa PGPAUD yang mengikuti PLP dalam pengetahuan mendidik anak atau pola pikir keilmuannya sudah cukup baik, hanya saja dalam beberapa pengaplikasian di lapangan masih diperlukan latihan untuk praktik mendidiknya seperti pada saat pengelolaan kelas, mengidentifikasi kesulitan anak, merancang program mingguan dan harian sesuai kebutuhan anak, dan penyedian serta penggunaan media permanen yang cocok untuk anak.

Dari ulasan di atas, terlihat bahwa dalam proses pembelajaran anak, diperlukannya pengetahuan atau ilmu mengenai mendidik anak, guru juga perlu memiliki pengalaman khusus dalam praktek mendidiknya yakni dengan adanya bimbingan secara terstruktur dan sistematis, terlebih lagi untuk lulusan calon guru PAUD, sehingga ketika guru melakukan praktek secara mandiri di satuan PAUD maka guru dapat memenuhi kebutuhan anak secara optimal dalam proses pembelajarannya. Maka dari itu dibutuhkan calon guru PAUD yang kedepannya dapat memenuhi kompetensi pedagogik tersebut. Bimbingan yang diperlukan selain dari mendapatkan konsep-konsep dasar keilmuan yang telah didapatkan, calon guru PAUD juga membutuhkan bimbingan praktek lapangan dari kepala sekolah dan guru pamong yang akan berhubungan langsung dengan keseharian calon guru khususnya di Taman Kanak-kanak.

Keterlibatan kepala sekolah dan guru pamong merupakan hal penting dalam kegiatan membimbing mahasiswa di TK saat dalam Program Latihan Profesi. Karena 
diharapkan dengan adanya bimbingan dari kepala sekolah dan guru pamong, mahasiswa dapat dihantarkan menjadi calon guru yang berkompenten yang salah satunya dapat memenuhi kompetensi pedagogik. Tentunya kepala sekolah dan guru pamong yang dapat membimbing mahasiswa dalam program PLP ini merupakan pembimbing yang tidak sembarang diajukan untuk membimbing mahasiswa. Kepala sekolah dan guru pamong harus memenuhi pesyaratan terlebih dahulu yakni minimalnya telah memiliki pengalaman dalam mengajar selama 5 tahun dan telah memiliki jabatan golongan III/a serta telah terdaftra secara administrasi (Panduan PPL, 2014). Dengan terpenuhinya syarat tersebut, kepala sekolah dan guru pamong diharapkan dapat memenuhi tugas dan perannya secara optimal dalam membimbing mahasiswa diantaranya dalam mensupervisi kegiatan mahasiswa secara berkesinambungan, memberikan tugas, memeriksa, mengomentari, dan menilai mengenai ketepatan dan kekurangan mahasiswa dalam proses bimbingan praktek di TK secara langsung (Panduan PPL, 2014).

\section{METODE}

Metode yang digunakan dalam penelitian ini adalah metode survei desktiptif. Alasan digunakannya metode survei dikarenakan peneliti bermaksud memperoleh dan mengumpulkan data mengenai suatu kondisi tanpa ada perlakuan sebelumnya

Subjek penelitian dalam penelitian ini adalah kepala sekolah dan guru pamong PLP PGPAUD FIP UPI tahun akademik 20142015 yang terdiri dari 7 orang kepala sekolah dan 24 guru pamong. Pengambilan subjek dilakukan dengan menggunakan teknik sampel purposive yakni penarikan sampel yang kriterianya sudah ditentukan oleh peneliti diantaranya:

a. Kepala sekolah dan guru pamong

b. Kepala sekolah dan guru pamong yang telah terlibat dalam administratif dan proses Program Latihan Profesi (PLP) PGPAUD FIP UPI pada tahun akademik 2014-2015.

Instrumen penelitian ini menggunakan angket tertutup dengan penilaian menggunakan skala likert berupa baik, cukup, dan kurang. Kompetensi Pedagogik memiliki aspek penting yang meliputi kemampuan merencanakan pembelajaran bagi anak usia dini, kemampuan mengimplementasikan pembelajaran bagi anak usia dini, dan kemampuan mengevaluasi pembelajaran bagi anak usia dini.

Sebelum disebarkan ke lapangan, dilakukan 2 tahapan uji instrumen, yaitu uji konstruk terhadap dua orang ahli, dan uji internal terdiri dari uji validitas menggunakan rumus product momen serta uji reliabilitas dengan bantuan SPSS versi 20.

Pada penelitian ini, teknik analisis data dalam penelitian kuantitatif menggunakan statistik, yaitu statistika deskriptif.

\section{HASIL DAN PEMBAHASAN}

Pendapat Kepala Sekolah dan Guru Pamong tentang Kompetensi Pedagogik Mahasiswa PLP PGPAUD FIP UPI Tahun Akademik 2014-2015.

\section{Pendapat Kepala Sekolah}

Pendapat kepala sekolah tentang kompetensi pedagogik mahasiswa PLP PGPAUD FIP UPI Tahun Akademik 20142015 dari 7 orang kepala sekolah memberikan kriteri baik dengan nilai 
$72,93 \%$, kriteria cukup dengan nilai $27,07 \%$, dan kriteria rendah dengan nilai $0 \%$.

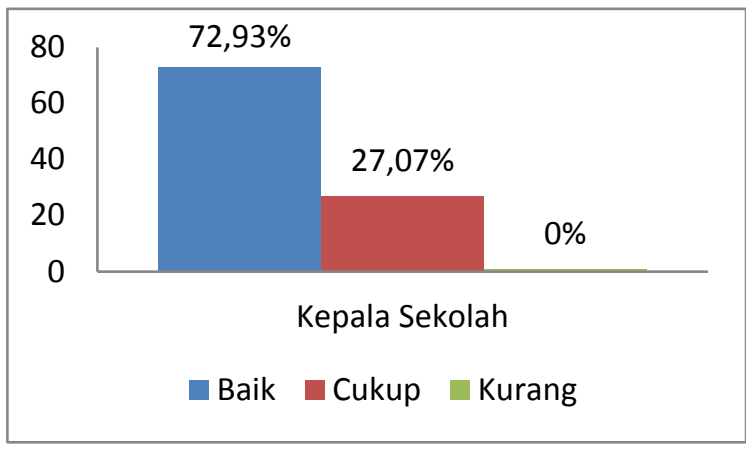

\section{Grafik 1. Pendapat Guru Pamong tentang Kompetensi Pedagogik Mahasiswa PLP PGPAUD FIP UPI Tahun Akademik 2014-2015}

Tingginya pendapat kepala sekolah tentang kompetensi pedagogik mahasiswa PLP dalam kriteria baik ini terlihat dari keseluruhan item tertinggi dari 3 sub penelitian yaitu kemampuan mahasiswa dalam merencanakan pembelajaran bagi anak usia dini, kemampuan mahasiswa dalam mengimplementasikan pembelajaran bagi anak usia dini, dan kemampuan mahasiswa dalam mengevaluasi pembelajaran bagi anak usia dini.

Berdasarkan hasil analisis penulis, terdapat tiga hal yang menjadi faktor yang mendukung baiknya pendapat kepala sekolah kompetensi pedagogik yang dimiliki yaitu 1) prestasi belajar mahasiswa, 2) peran guru pamong, dan 3) Motivasi

\section{Prestasi belajar mahasiswa}

Pertama yakni dari prestasi belajar mahasiswa. Prestasi belajar merupakan faktor penunjang untuk guru dapat menguasai pembelajaran dikelas dimana mahasiswa yang memiliki pengetahuan yang luas, dan penguasaan terhadap materi pembelajaran akan lebih mudah dan percaya diri dalam menguasai pembelajaran, sesuai dengan Maria Liakopuou dalam international Jurnal of Humanities dan social Science Vol.1 NO. 21 (Special IssueDecember 2011) menyatakan bahwa pengetahuan dan prestasi guru dapat menunjang efektifitas pembelajaran (Ulin \& Oktarina, 2014). Hal ini juga sejalan dengan informasi yang didapatkan peneliti bahwa nilai Indeks Prestasi Kumulatif PGPAUD yang mengikuti PLP termasuk dalam katagori sangat memuskan dimana nilai ratarata IPK mahasiswa yang didapat dari semester 1-7 adalah 3,48. Nilai IPK yang tergolong sangat memuaskan ini tentunya didapatkan dari nilai akumulasi mata kuliah yang sudah ditempuh oleh mahasiswa sebagai bentuk hasil penilaian pemahaman konsep-konsep kependidikan dan keterampilan dengan bimbingan dosen pengampuh mata kuliah. Dimana pengetahuan dan keterampilan yang telah didapatkan oleh mahasiswa akan diimplementasikan pada pembelajaran di kelas sesungguhnya dan kehidupan di sekolah sesuangguhnya. Sejalan dengan pendapat Darmasih dan Juarsih (2014) bahwa pengetahuan merupakan salah satu faktor yang menunjang untuk mewujudkan kinerja guru yang diharapkan, selebihnya adalah pengalaman dan motivasi (kemauan) guru untuk dapat menggunakan pengetahuannya dalam melaksanakan tugas keprofesiannya.

\section{Peran guru pamong}

Faktor yang dapat mempengaruhi kesiapan mahasiswa menjadi guru adalah adanya peran guru pamong dan prestasi belajar (Ulin \& Oktarina, 2004). Hal ini sejalan dengan tugas guru pamong dalam program PLP yaitu membimbing dan membantu mahasiswa untuk lebih mudah mengenal kondisi siswa, mengetahui 
yang menjadi kelebihan dan kekurangan pembelajaran yang telah dilakukan mahasiswa, serta memberikan saran dan motivasi kepada mahasiswa untuk dapat lebih berkompeten dalam menjalani tugas sebagai calon guru (Panduan PPL, 2014). Hal ini didukung dnegan hasil wawancara dengan mahasiswa PLP bahwa guru pamong sangat berperan dalam membantu mahasiswa pada saat mahasiswa memiliki kesulitan baik saat merencanakan pembelajaran, implementasi pembelajaran, dan melakukan evaluasi pembelajaran.

\section{Motivasi}

Tinggi rendahnya motivasi dapat menentukan tinggi rendahnya usaha atau semangat seseorang untuk beraktifitas, dan tentu saja tinggi rendahnya semangat akan menentukan hasil yang diperoleh (Sanjaya, 2010, hlm. 249). Sesuai pernyataan di atas melalui hasil wawancara kepala sekolah dimana guru pamong menginformasikan kepada kepala sekolah bahwa mahasiswa mudah untuk dibimbing dan diarahkan oleh guru pamong pada saat melakukan perbaikan dalam proses pembelajarannya. Menurut Sagala (2010, hlm. 253) “...motivasi bukan hanya dapat menggerakan seseorang untuk beraktivitas, tetapi melalui motivasi juga orang tersebut akan mengarahkan aktivitasnya secara bersungguh-sungguh untuk mencapai tujuan tertentu".

\section{Pendapat Guru Pamong}

Pendapat guru pamong tentang kompetensi pedagogik mahasiswa PLP PGPAUD FIP UPI Tahun Akademik 20142015 dari 24 orang guru pamong berkecenderungan baik dengan nilai $62,06 \%$, berkecenderungan cukup dengan nilai
$36,93 \%$, dan berkecenderungan rendah dengan nilai $0,99 \%$.

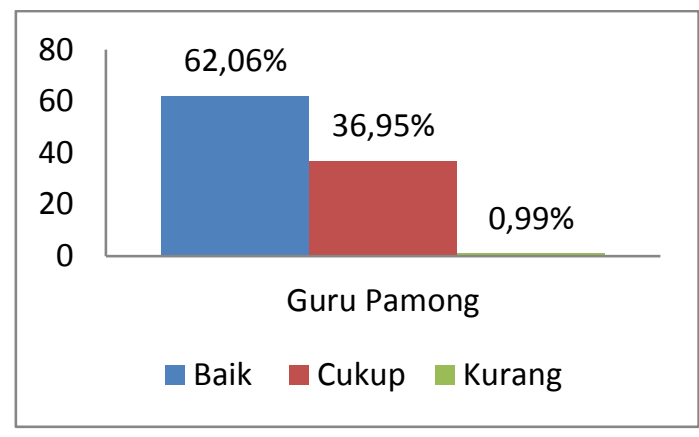

Grafik 2.Pendapat Guru Pamong tentang Kompetensi Pedagogik Mahasiswa PLP PGPAUD FIP UPI Tahun Akademik 2014-2015

Sama halnya seperti kepala sekolah, guru pamong juga memiliki pendapat yang baik tentang kompetensi mahasiswa PLP yang baik. Tentunya hal tersebut didukung oleh faktor-faktor yang telah dijelaskan sebelumnya yaitu didukung oleh hasil belajar, adanya peran guru pamong, dan adanya motivasi.

Bila dilihat dari hasil temuan pendapat guru pamong dengan kepala sekolah ternyata kedua subjek memiliki kecenderungan yang sama-sama baik, hanya saja nilai persentase yang diberikan kepala sekolah lebih tinggi dibandingkan dengan nilai persentase guru pamong. Hal ini terjadi dapat dipengaruh oleh sebaran subjek yang tidak seimbang dimana kepala sekolah memiliki sebaran subjek 1 banding 3 yaitu jumlah sampel kepala sekolah sebanyak 7 orang dan jumlah sampel guru pamong sebanyak 24 orang. Semakin banyak subjek yang dimintai pendapat, maka semakin beragam pendapat yang dipeoleh.

Hasil pendapat antara dua subjek ini dapat dipengaruhi oleh faktor komponen affect (perasaan atau emosi) dimana guru 
dan kepala sekolah melihat secara langsung praktek mahasiswa saat program PLP. Namun bila dilihat dari intensitasnya guru pamong lebih sering membimbing dan mengikuti keseharian mahasiswa dalam melaksanakan program PLP. Hal ini sejalan dengan tugas guru pamong yaitu mengamati, menilai, melatih, memberi tugas mahasiswa dan membantu mahasiswa untuk beradaptasi di lingkungan sekolah (Pandual PPl 2014). Sedangkan kepala sekolah lebih bertugas sebagai pemimpin atau organisatori. Kepala sekolah lebih banyak mengelola atau menjembatani program PPL di sekolah dengan pihak universitas seperti memberikan informasi yang diperlukan universitas demi terlaksananya program PLP dengan baik. Sejalan dengan hasil wawancara dengan kepala sekolah bahwa kepala sekolah hanya melihat unjuk kerja mahasiswa dalam beberapa kali saja, dan tidak mengetahui secara langsung dan mendalam bagaimana kesulitan mahasiswa dalam praktiknya, sedangkan guru pamong lebih mengetahui secara terperinci dimana kesulitan mahasiswa dan bagaimana sejauh mana kemajuan mahasiswa dari hari kehari.

\section{Pendapat Kepala Sekolah dan Guru} Pamong tentang Kompetensi Pedagogik Mahasiswa PLP PGPAUD Tahun Akademik 2014-2015 Berdasarkan Aspek Kemampuan Merencanakan

\section{Pembelajaran bagi Anak Usia Dini.}

\section{Pendapat Kepala Sekolah}

Pendapat kepala sekolah tentang kompetensi pedagogik mahasiswa PLP PGPAUD FIP UPI Tahun Akademik 20142015 berdasarkan aspek kemampuan merencanakan pembelajaran bagi anak usia dini dari 7 orang kepala sekolah yang memberikan kriteria baik dengan nilai
$74,29 \%$, kriteria cukup dengan nilai $25,71 \%$, dan kriteria rendah dengan nilai $0 \%$.

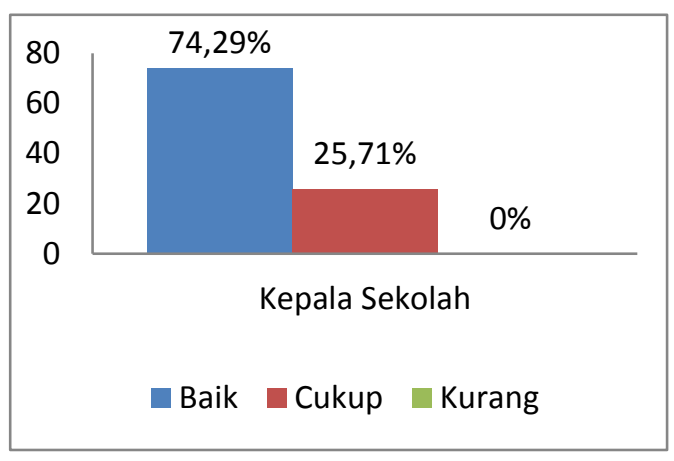

Grafik 3. Pendapat Kepala Sekolah tentang Kompetensi Pedagogik Mahasiswa PLP PGPAUD FIP UPI Tahun Akademik 2014-2015 Berdasarkan Aspek Kemampuan Merecanakan Pembelajaran bagi Anak Usia Dini

Baiknya pendapat kepala sekolah tentang kompetensi pedagogik mahasiswa PLP PGPAUD berdasarkan aspek merencanakan pembelajaran bagi anak usia dini ini terlihat dari tingginya skor item yang diberikan oleh kepala sekolah terhadap kemampuan mahasiswa dalam menentukkan dan merumuskan indikator, materi, media, langkah-langkah pembelajaran, teknik penilaian dan rancangan pelaksanaan pembelajaran. Hal ini sejalan dengan hasil jajak pendapat dengan kepala sekolah bahwa mahasiswa PLP sudah memiliki kemampuan yang baik dalam merencanakan pembelajaran bagi anak usia dini, dimana kepala sekolah juga mendapatkan informasi dari guru pamong bahwa mahasiswa dapat dibimbing dan diarahkan guru pamong pada saat membuat perencanaan pembelajaran hingga dapat membuat perncanaan pembelajaran dengan mandiri. selain itu mahasiswa berpendapat bahwa mereka merasa sudah bisa menentukan dan 
merumuskan komponen proses pembelajaran dengan mandiri.

Pernyataan diatas didukung dengan data nilai mata kuliah perencanaan pembelajaran anak usia dini. Dari 35 orang mahasiswa PLP PGPAUD, mahasiswa yang memperoleh nilai A sebanyak $42,85 \%$, mahasiswa yang memperoleh nilai $\mathrm{B}$ sebanyak $57,15 \%$, dan mahasiswa yang memperoleh nilai $\mathrm{C}$ sebanyak 0\%. Hal ini sejalan dengan hasil penelitian lain bahwa terdapat pengaruh positif antara prestasi belajar mata kuliah perencanaan pengajaran terhadap prestasi belajar praktik pengalaman lapangan (Wahyudi, 2009). Dari pemaparan di atas terlihat bahwa tidak menutup kemungkinan prestasi belajar mahaiswa dalam mata kuliah perencanaan pembelajaran anak usia akan dapat berpengaruh positif terhadap praktik di lapangan.

\section{Pendapat Guru Pamong}

Pendapat guru pamong tentang kompetensi pedagogik mahasiswa PLP PGPAUD FIP UPI Tahun Akademik 20142015 berdasarkan aspek kemampuan merencanakan pembelajaran bagi anak usia dini dari 24 orang guru pamong memberikan kriteria baik dengan nilai $67,91 \%$, kriteria cukup dengan nilai $31,67 \%$, dan kriteria rendah dengan nilai $0,42 \%$.

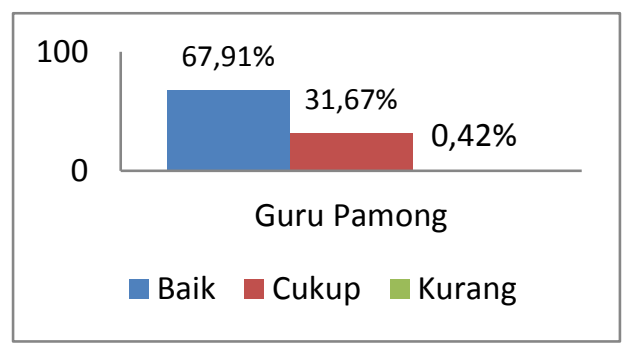

Grafik 4. Pendapat Guru Pamong tentang Kompetensi Pedagogik Mahasiswa PLP PGPAUD FIP UPI Tahun Akademik 2014-2015 Berdasarkan

\section{Aspek Merecanakan Pembelajaran bagi Anak Usia Dini}

Baiknya pendapat guru pamong tentang kompetensi pedagogik mahasiswa PLP PGPAUD berdasarkan aspek kemampuan merencanakan pembelajaran bagi anak usia dini ini terlihat dari tingginya pemilihan item-item perencanaan pembelajaranoleh guru pamong, sama seperti item-item yang dipilih oleh kepala sekolah. Namun yang berbeda dengan kepala sekolah adalah guru pamong memberikan kriteria cukup terhadap kemampuan mahasiswa dalam menentukan teknik penilain. Hal ini sejalan dengan hasil jajak pendapat dengan guru pamong bahwa mahasiswa PLP sudah cukup baik dalam merencanakan pembelajaran diantaranya pada saat menyususun rencana pelaksanaan pembelajaran, dimana mahasiswa mampu untuk mengikuti kebijakan sekolah dalam pembuatan rancangan pelaksanaan pembelajaran. selain itu guru pamong juga berpendapat bahwa mahasiswa memiliki motivasi diri untuk melakukan perbaikan atau mengikuti arahan yang telah diberikan oleh guru pamong. Hal ini sejalan dengan pendapat Sagala (2010, hlm. 253) "....motivasi bukan hanya dapat menggerakan seseorang untuk beraktivitas, tetapi melalui motivasi juga orang tersebut akan mengarahkan aktivitasnya secara bersungguh-sungguh untuk mencapai tujuan tertentu".

Pendapat Kepala Sekolah dan Guru Pamong tentang Kompetensi Pedagogik Mahasiswa PLP PGPAUD Tahun Akademik 2014-2015 Berdasarkan Aspek Kemampuan Mengimplmentasikan Pembelajaran bagi Anak Usia Dini. 


\section{Pendapat Kepala Sekolah}

Pendapat kepala sekolah tentang kompetensi pedagogik mahasiswa PLP PGPAUD FIP UPI Tahun Akademik 20142015 berdasarkan aspek kemampuan mengimplementasikan pembelajaran bagi anak usia dini dari 7 orang kepala sekolah memberikan kriteria baik dengan nilai $73,68 \%$, kriteria cukup dengan nilai $26,32 \%$, dan kriteria rendah dengan nilai $0 \%$.

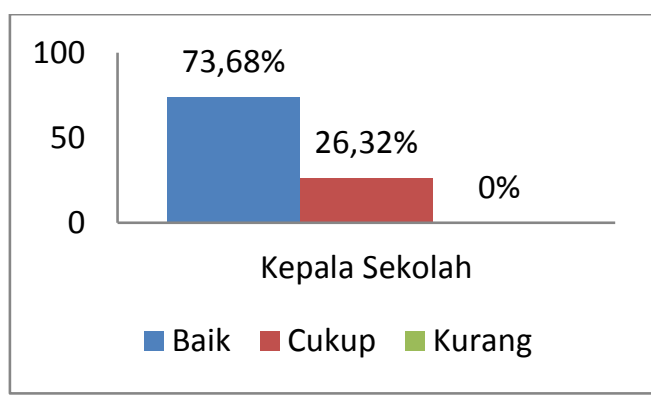

Grafik 5. Pendapat Kepala Sekolah tentang Kompetensi Pedagogik Mahasiswa PLP PGPAUD FIP UPI Tahun Akademik 2014-2015 Berdasarkan Aspek Kemampuan Mengimplementasikan Pembelajaran bagi Anak Usia Dini

Baiknya pendapat kepala sekolah tentang kompetensi pedagogik mahasiswa PLP PGPAUD berdasarkan aspek kemampuan mengimplementasikan pembelajaran bagi anak usia dini ini terlihat dari tingginya skor item kemampuan mahasiswa dalam mengimplementasikan pembelajaran yang diberikan kepala sekolah seperti kemampuan mahasiswa dalam menyiapkan alat dan bahan ajar di dalam kelas, menjelaskan langkah-langkah kegiatan pembelajaran yang akan dilakukan melalui pemberian contoh dengan benda konkrit, melibatkan anak untuk mencari informasi yang luas dan dalam tentang tema dna topik materi yang akan dipelajari, menggunakan beragam metode pembelajaran secara tepat dengan pendekatan bermain sambil belajar, memberikan kesempatan kepada anak untuk berpartisipasi secara berkelompok, melibatkan anak secara aktif dalam setiap kegiatan, memberikan kesempatan kepada anak untuk mengekspresikan karyanya, memberikan penguatan perilaku secara verbal ataupun non verbal kepada anak secara tepat memberikan kebebasan kepada anak untuk memilih kegiatan yang diinginkan, melakukan kegiatan pembiasaan terhadap anak dengan mengaitkan nilai budi pekerti sesuai dengan nilai sosial budaya dan nilai-nilai agama, menjawab pertanyaan anak dengan menggunakan kalimat yang mudah dipahami, memberikan kesempatan kepada anak untuk dapat menceritakan kembali pengalaman kegiatan belajar yang telah dilakukan, dan memberikan kesempatan kepada anak untuk menceritakan hasil karyanya.

Hal tersebut sejalan dengan hasil jajak pendapat dengan kepala sekolah bahwasanya kemampuan mahasiwa dalam mengimplementasikan pembelajaran sudah baik, beberapa yang perlu lebih dimaksimalkan adalah mahasiswa dapat menyiapkan media atau alat peraga lebih baik lagi, seperti dalam ukuran media yang sesuai untuk anak usia dini sehingga dapat dilihat oleh semua anak dan lebih konkrit, tidak hanya maksimal disaat sedang ujian saja. Sejalan dengan pendapat Darmasih dan Juarsih (2014, hlm. 82) bahwa

"Berdasarkan teori kinerja tentang sumber belajar atau media pembelajaran merupakan salah satu faktor yang menentukan kinerja pada pengguna sumber belajar atau media pembelajaran itu. Selebihnya adalah pengalaman dan motivasi (kemauan) menggunakan pengetahuan 
tersebut dalam pelaksanaan tugas pembelajaran"

Selain itu dari hasil jajak pendapat mahasiswa bahwa mahasiswa merasa kesulitan untuk meyediakan media atau alat dan bahan yang lebih konkrit di luar sekolah karena keterbatasan materi yang dimiliki berupa dana, waktu serta tuntutan dari sekolah untuk membuat media yang tepat.

\section{Pendapat Guru Pamong}

Pendapat guru pamong tentang kompetensi pedagogik mahasiswa PLP PGPAUD FIP UPI Tahun Akademik 20142015 berdasarkan aspek kemampuan mengimplementasikan pembelajaran bagi anak usia dini dari 24 orang guru pamong memberikan kriteria baik dengan nilai $64,25 \%$, kriteria cukup dengan nilai $34,87 \%$, dan kriteria rendah dengan nilai $0,88 \%$.

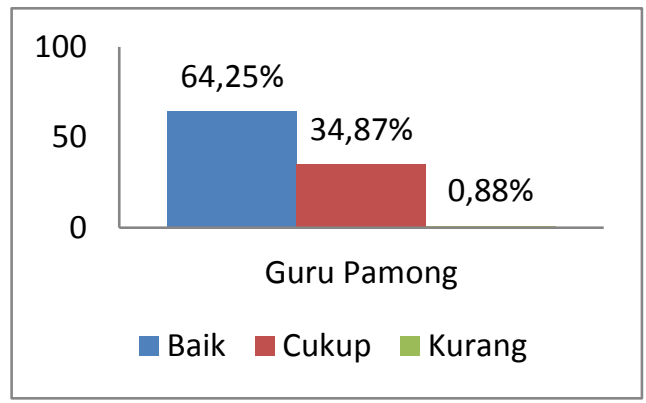

Grafik 6. Pendapat Guru Pamong tentang Kompetensi Pedagogik Mahasiswa PLP PGPAUD FIP UPI Tahun Akademik 2014-2015 Berdasarkan Aspek Kemampuan Mengimplementasikan Pembelajaran bagi Anak Usia Dini

Tingginya kecenderungan guru pamong terhadap kompetensi pedagogik mahasiswa PLP PGPAUD berdasarkan aspek kemampuan mengimplementasikan pembelajaran bagi anak usia dini ini terlihat dari guru pamong yang memberikan skor tinggi pada item-item kemampuan mahasiswa melakukan kegiatan memotivasi, apresepsi, bimbingan, eksplorasi, elaborasi, konfirmasi, dan review.

Baiknya kecenderungan pendapat guru pamong tentang kompetensi pedagogik mahasiswa PLP PGPAUD FIP UPI berdasarkan aspek kemampuan mengimplementasikan pembelajaran ini didukung dengan baiknya mahasiswa dalam menyusun perencanaan pelaksanaan pembelajaran sehingga membantu mahasiswa untuk dapat lebih siap dalam melakukan kegiatan pelaksanaan pembelajaran. Sejalan dengan pendapat Fadillah (2012, hlm. 135) bahwa:

"Fungsi utama dari perencanaan pelaksanaan pembelajaran yaitu fungsi perencanaan dan fungsi pelaksanaan. Fungsi perencanaan, yaitu rencana pelaksanaan pembelajaran hendaknya dapat mendorong guru lebih siap melakukan kegiatan pembelajaran dengan perencanaan yang matang. Sedangkan fungsi pelaksanaa, rencana pelaksanaan pembelajaran harus disusun secara sistemik dan sistematis, utuh, menyeluruh dengan beberapa kemungkinan penyesuaian dalam situasi pembelajaran yang aktual."

Hal ini juga sejalan dengan hasil persentase kecenderungan guru pamong yang sama-sama termasuk ke dalam kriteria baik yaitu dengan nilai $67,91 \%$. Dari penjelasan diatas tidak menutup kemungkinan bahwa mahasiswa yang sudah memiliki perencanaan yang baik akan terbantu untuk mengetahui langkah-langkah yang akan dilakukan dalam proses pembelajaran melalui penentuan dan perumusan komponen-komponen pembelajaran sesuai dengan karakteristik perkembangan dan prinsip-prinsip belajar anak usia dini ini akan membantu 
mahasiswa menjadi lebih terarah dalam proses pelaksanaan pembelajarannya. Pernyataan di atas sesuai dengan pendapat Anwar \& Harmi (2010, hlm. 31) bahwa "Perencanaan pebelajaran akan menjadi sangat penting karena dapat berfungsi sebagai dasar, pemandu, alat kontrol, dan arah pembelajaran."

Pendapat Kepala Sekolah dan Guru Pamong tentang Kompetensi Pedagogik Mahasiswa PLP PGPAUD Tahun Akademik 2014-2015 Berdasarkan Aspek Kemampuan Mengevaluasi Pembelajaran bagi Anak Usia Dini.

\section{Pendapat Kepala Sekolah}

Pendapat kepala sekolah tentang kompetensi pedagogik mahasiswa PLP PGPAUD FIP UPI Tahun Akademik 20142015 berdasarkan aspek kemampuan mengevaluasi pembelajaran bagi anak usia dini dari 7 orang kepala sekolah memberikan kriteria baik dengan nilai $76,20 \%$, kriteria cukup dengan nilai $23,80 \%$, kriteria rendah dengan nilai $0 \%$.

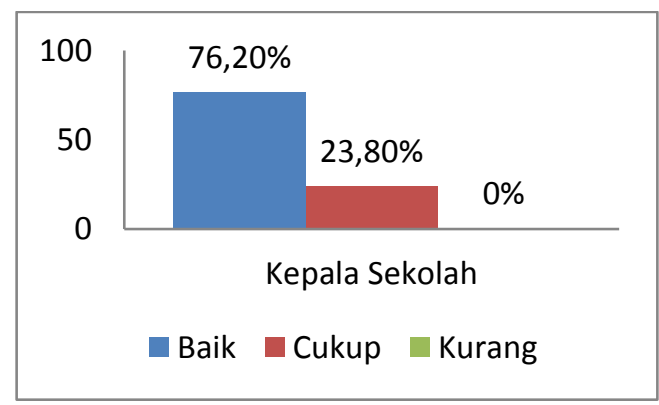

Grafik 7. Pendapat Kepala Sekolah tentang Kompetensi Pedagogik Mahasiswa PLP PGPAUD FIP UPI Tahun Akademik 2014-2015 Berdasarkan Aspek Kemampuan Mengevaluasi Pembelajaran bagi Anak Usia Dini
Tingginya kecenderungan pendapat kepala sekolah tentang kompetensi pedagogik mahasiswa PLP PGPAUD FIP UPI berdasarkan aspek kemampuan mengevaluasi pembelajaran bagi anak usia dini dalam kriteria baik dapat dilihat dari item-item tertinggi yaitu kemampuan mahasiswa dalam menggunakan teknik evaluasi, mengembangkan alat evaluasi, mengelola hasil evaluasi, melaporkan hasil evaluasi dan melakukan tindak lanjut evaluasi. Hal tersebut sejalan dengan hasil jajak pendapat dengan kepala sekolah bahwasanya mahasiswa PLP sudah baik dalam melaksanakan evaluasi pembelajaran.

\section{Pendapat Guru Pamong}

Pendapat guru pamong tentang kompetensi pedagogik mahasiswa PLP PGPAUD FIP UPI Tahun Akademik 20142015 berdasarkan aspek mengimplementasikan pembelajaran bagi anak usia dini dari 24 orang guru pamong memberikan kriteria baik dengan nilai $47,68 \%$, kriteria cukup dengan nilai 51,39\%, dan kriteria rendah dengan nilai $0,93 \%$.

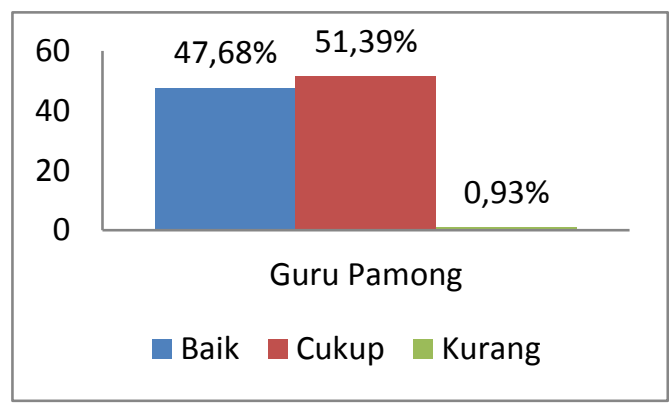

Grafik 8. Pendapat Guru Pamong tentang Kompetensi Pedagogik Mahasiswa PLP PGPAUD FIP UPI Tahun Akademik 2014-2015 Berdasarkan Aspek Mengimplementasikan Pembelajaran bagi Anak Usia Dini 
Tingginya kecenderungan pendapat guru pamong tentang kompetensi pedagogik mahasiswa PLP PGPAUD berdasarkan aspek kemampuan mengevaluasi pembelajaran bagi anak usia dini dalam kriteria cukup, sejalan dengan hasil jejak pendapat guru pamong bahwa mahasiswa sudah cukup baik untuk melakukan kegiatan evaluasi pembelajaran hanya saja masih ada beberapa kemampuan mahasiswa yang perlu lebih ditingkatkan seperti mahasiswa harus dapat merancang sendiri penilaian selain dari yang disarankan oleh guru pamong agar mahasiswa dapat mengetahui kekurangan dan potensi anak secara mendalam diantaranya dengan cara membuat instrumen penilaian sendiri. Selain itu mahasiswa juga harus berhati-hati dalam mendiagnosis tumbuh kembang anak dengan cara memberikan penyampaian perkembangan atau laporan penilaian dengan bahasa yang bijak. Kemudian mahasiswa juga harus aktif mencari metode khusus untuk membuat rencana pelayanan program bimbingan selain dari mendapatkan arahan dan bimbingan dari guru pamong.

\section{SIMPULAN}

Berdasarkan hasil penelitian dalam menjawab rumusan masalah dan tujuan penelitian, maka data penelitian menghasilkan beberapa kesimpulan, yaitu:

1. Pada umumnya pendapat kepala sekolah dan guru pamong tentang kompetensi pedagogik mahasiswa PLP PGPAUD FIP UPI tahun akademik 20142015 memberikan pendapat baik yaitu sebesar $72,93 \%$ dan $62,06 \%$.

2. Pada umumnya pendapat kepala sekolah dan guru pamong tentang kompetensi pedagogik mahasiswa PLP PGPAUD FIP UPI tahun akademik 20142015 berdasarkan aspek merencanakan pembelajaran bagi anak usia dini memberikan pendapat baik yaitu sebesar $74,29 \%$ dan $67,91 \%$.

3. Pada umumnya pendapat kepala sekolah dan guru pamong tentang kompetensi pedagogik mahasiswa PLP PGPAUD FIP UPI tahun akademik 20142015 berdasarkan aspek mengimplementasikan pembelajaran bagi anak usia dini memberikan pendapat baik yaitu sebesar 73,68\% dan 64,25\%.

4. Pada umumnya pendapat kepala sekolah tentang kompetensi pedagogik mahasiswa PLP PGPAUD FIP UPI tahun akademik 2014-2015 berdasarkan aspek mengevaluasi pembelajaran memberikan pendapat baik yaitu sebesar 76,20\%. Pendapat guru pamong pada umumnya tentang kompetensi pedagogik mahasiswa PLP PGPAUD FIP UPI tahun akademik 2014-2015 berdasarkan aspek mengevaluasi pembelajaran bagi anak usia dini memberikan pendapat cukup yaitu sebesar $51,39 \%$. 


\section{DAFTAR PUSTAKA}

Anwar, K. \& Harmi, H. (2011). Perencanaan Sistem Pembelajaran Kurikulum Tingkat Satuan Pendidikan. Bandung: Alfabeta.

Darmasih, \& Juarsih, C. (2014). Kegiatan Pembelajaran yang Mendidik: Dalam Rangka Implementasi Standar Proses Pendidikan Siswa. Jakarta: Asdi Mahastya.

Fadillah, M. (2012). Desain Pembelahjaran PAUD:Tinjauan Teoritik \& Praktik. Yogjakarta: Ar-Ruzz Media.

Farwan, dkk. (TT). Pemahaman Guru PAUD terhadap Kompetensi Pedagogik.

Isjoni. (2006). Pendidikan Sebagai Investasi Masa Depan. Jakarta: Yayasan Obor Indonesia.

Mariana, R. (2008). Pengembangan Profesi Guru TK. Bandung: Universitas Pendidikan Indonesia.

Nuraini, Y.S. (2012). Konsep Dasar Pendidikan Anak Usia Dini. Jakarta: Permata Puri Media.

Sagala, S. (2009). Kemampuan Profesional Guru dan Tenaga Kependidikan. Bandung: Alfabeta.

Syaripudin, T. (2009). Pedagogik Teoritis Sistematis. Bandung: Percikan Ilmu.

Peraturan Menteri Pendidikan Nasional Nomor 16 Tahun 2007.

Peraturan Pemerintah Nomor 19 Tahun 2005. Undang-Undang RI Nomor 14 Tahun 2005 (Pasal 2).

Undang-undang Nomor 20 Tahun 2003 tentang Sistem Pendidikan Nasional (pasal 1 butir 14)

Sanjaya, Wina. (2010). Strategi Pembelajaran Berorientasi Standar Proses Pendidikan. Jakarta : Prenada Media Group.
Rachmawati, T \& Daryanto. (2013). Penilaian Kinerja Profesi Guru Dan Angka Kreditnya. Yogyakarta: Gava Media.

Peraturan Pemerintah Nomor 74 Tahun 2008 Tentang Guru.

Ulin dan Oktarina. (2014). "Pengaruh Minat Profesi Guru, Locus of Internal, Pengaruh Guru Pamong dan Prestasi Belajar terhadap Kesiapan Mahasiswa Menjadi Gueu pada Jurusan Pendidikan Ekonomi 66 Fakultas Ekonomi Universitas Negeri Semarang." Economic Education Analysis Journal, 3(2), 2252-6544.

Wahyudi, M. (2009). Analisis Faktor-faktor yang Mempengaruhi Penggunaan Informasi Akuntansi Pada Usaha Kecil dan Menengah (UKM) di Yogyakarta. 